\title{
Bariatric Surgery as Efforts to Overcome Obesity and Opportunities Medical Tourism
}

\section{Rusdi ${ }^{1}$ and Amal Chalik Sjaff²}

${ }^{1}$ Hospital Administration Programme, Faculty of Public Health, University of Indonesia, Depok, West Java, Indonesia

${ }^{2}$ Health Administration and Policy Department, Faculty of Public Health, University of Indonesia, Depok, West Java, Indonesia

\section{Abstract}

Obesity management can be done in various ways, including dietary regulation, drug use, and a surgery called bariatric surgery. Of these three ways, surgery is considered the most effective way to overcome obesity in the long term. Bali being able to implement this surgery can in addition to being a tourist destination can also be one of the medical tourism spots to undergo bariatric surgery. Bali has performed bariatric surgery on nine patients so far, consisting of one Indonesian

Corresponding Author: Amal Chalik Sjaff amal.c.sjaaf@gmail.com

Received: 17 October 2018 Accepted: 5 November 2018 Published: 5 December 2018

Publishing services provided by Knowledge E

(c) Rusdi and Amal Chalik Sjaff. This article is distributed under the terms of the Creative Commons Attribution License, which permits unrestricted use and redistribution provided that the original author and source are credited.

Selection and Peer-review under the responsibility of the 2 nd ICHA Conference Committee. citizen and eight foreign tourists. Of the foreign patients, six were Australian citizens and two French citizens. The patients recovered within two weeks of surgery. They began to feel limited appetite and started exercising; the average patient's weight was reduced by $6 \mathrm{~kg}$ within six weeks after surgery. This action has been widely developed including in Indonesia, especially Bali. Rates offered by Bali are also cheaper when compared with Australia and Europe. The success rate of this action was even higher at $28 \%$, compared with lifestyle changes and pharmacology. This is an opportunity for Indonesia and Bali to attract foreign tourists to conduct medical tourism. To overcome the challenges of competitors from neighbouring countries like Malaysia and Singapore, a broader promotion is needed at the international level and always maintain a good image in patients who have undergone bariatric surgery in Bali. Bariatric surgery is the most effective curative action for obese people. Bali as a tourist destination also has great opportunities as a destination of medical tourism.

Keywords: bariatric, medical tourism, obesity

\section{Introduction}

Obesity is a worldwide problem in both developed and developing countries because of its increasing prevalence in adults and children [1]. Obesity was determined based on body mass index (BMI) in adults $>25 \mathrm{~kg} / \mathrm{m} 2$ as overweight and $>30 \mathrm{~kg} / \mathrm{mz}$ as obesity. But for Asian people this criterion is different where BMI $>23 \mathrm{~kg} / \mathrm{m} 2$ is already 
a criterion for overweight. This is because the percentage of Asian body fat (especially abdominal obesity) is 7-10\% higher than Caucasian [2].

A person with obesity has the potential to develop metabolic and degenerative diseases later in life, one of which is cardiovascular disease and type 2 diabetes mellitus [3]. Therefore, risk factors for cardiovascular disease include dyslipidaemia in obese patients should be evaluated. The prevalence of overweight is most prevalent in Latin America and the Caribbean (4.4\%), then Africa (3.9\%), and Asia (2.9\%) [4]. In Indonesia itself, based on Basic Health Research (Riskesdas) data in 2013, it was found that the most obese age groups were in the age group $>18$ years. This increase reached $32.9 \%$ when compared with data in 2010 which only $15.5 \%$ [5].

Many strategies, such as diet, weight-loss programs and medical therapy fail to show long-term weight loss. Bariatric surgery is a cost-effective intervention that provides long-term weight loss and can treat comorbid conditions effectively [6]. Indonesia has been able to carry out bariatric operations, particularly Bali.

Bali is one of the tourist destinations that the number of foreign tourists visiting increased in the last 1 (one) year. The number of foreign tourists to Bali in June 2016 raised $12.83 \%$ compared with June 2015 and increased by $2.86 \%$ compared with May 2016. According to the nationality, the most frequent tourists coming to Bali in June 2016 are tourists from Australia, China, India, Japan and the UK with percentage of $26.23 \%, 19.20 \%, 4.58 \%, 4.47 \%$ and $4.38 \%$, respectively [7]. Bali is the place that comfort is available on the island. This is one of the opportunities for the implementation of medical tourism related to bariatric surgery.

\section{Methods}

This is a literature study to analyse tourism potential of bariatric surgery by using thematic approach.

\section{Results and Discussion}

Obesity is caused by an imbalance of the amount of energy that enters with the required by the body. The body needs energy for various biological functions such as physical growth, development, activity, health maintenance [5]. Obesity that occurs at the age of children and adolescents can increase the incidence of diabetes mellitus (DM) type 2 . In addition, children are also at risk for obesity in adulthood and potentially impaired glucose metabolism and degenerative diseases such as heart disease, blood 
vessel obstruction, etc. Therefore, obesity should be treated as early as possible to avoid comorbidities due to obesity. One of the actions that can lose weight in the long term is bariatric surgery. In this action, manipulation of the gaster is done so that the gaster size becomes smaller. Smaller gastric size will reduce the capacity of the stomach to receive food and provide a feeling of satiety faster [6].

This action has been developed in many countries around the world including in Indonesia, especially Bali. Bali has been able to meet the availability of human resources (HR) for this procedure. Rates offered by Bali are also cheaper when compared with Australia and Europe as shown in Table 1. The success rate of this action was even higher at $28 \%$, compared with lifestyle and pharmacological changes with successive percentages of $11 \%$ and $8 \%$ [8]. This is an opportunity for Indonesia and Bali in particular to attract foreign tourists to conduct medical tourism.

TABLE 1: Bariatric surgery rates in Bali.

\begin{tabular}{|c|c|}
\hline Item & Tariff \\
\hline Radiology & Rp 195,000 \\
\hline Laboratory & Rp 3,000,000 \\
\hline ECG & Rp 120,000 \\
\hline Basic Nursing & Rp 220,000 \\
\hline Room HCU & Rp 750,000 \\
\hline Room Ward & Rp 2,400,000 \\
\hline Nursing HCU & Rp 350,000 \\
\hline Nursing Care Ward & $\operatorname{Rp} 750,000$ \\
\hline Surgery & Rp 45,612,000 \\
\hline Bariatric equipment & $\operatorname{Rp} 60,660,600$ \\
\hline Medication & Rp $12,568,604$ \\
\hline Consumable & Rp 785,000 \\
\hline Medical equipment & Rp 7,000,000 \\
\hline $\begin{array}{l}\text { Surgical } \\
\text { Instrument/Equipment }\end{array}$ & $\operatorname{Rp} 7,560,177$ \\
\hline Doctor visitation & Rp 930,000 \\
\hline Specialist counsel & $\operatorname{Rp} 600,000$ \\
\hline Histopathology Radicality & Rp 1,118,000 \\
\hline Administration & Rp 150,000 \\
\hline Total & Rp $144,769,381$ \\
\hline Rounding & Rp $150,000,000$ \\
\hline
\end{tabular}

Neighbouring countries are also Indonesia's competitors in this surgery. Competitive countries that are the main competitors are Malaysia and Singapore because the country is able to provide cheaper rates. Indonesia has not been able to compete with the tariffs they provide because of the high cost of tools and taxes. This is because 
Indonesia still has to bring in tools from abroad. To overcome this challenge, a broader promotion is needed at the international level and always maintains a good image in patients who have undergone bariatric surgery in Bali. The goal is to maintain foreign tourists' trust in order to keep Bali as a medical tourism destination in overcoming obesity.

\section{Conclusion}

Based on the discussion, it can be concluded that bariatric surgery is the most effective curative action for obese people. Bali as a tourist destination also has great opportunities as a destination of medical tourism. To achieve this goal, a more massive international campaign is needed by hospitals capable of carrying out these actions.

\section{References}

[1] Fu, W. P. C., et al. (2003). Screening for childhood obesity: International vs population-specific definitions. Which is more appropriate? International Journal of Obesity, vol. 27, no. 9, pp. 1121-1126.

[2] Haslam, D. W. and James, W. P. T. (2005). Obesity, in Lancet, vol. 366, no. 9492, pp. 1197-1209.

[3] Sjarif, D. (2004). Anak gemuk, apakah sehat?

[4] de Onis, M. and Blössner, M. (2000). Prevalence and trends of overweight among preschool children in developing countries. The American Journal of Clinical Nutrition, vol. 72, no. 4, pp. 1032-1039.

[5] Kementerian Kesehatan Republik Indonesia. (2014). Riset Kesehatan Dasar Tahun 2013. Retrieved from www.depkes.go.id/resources/download/general/ Hasil Riskesdas 2013.pdf (accessed on 12 October 2016).

[6] Kim, D. H., Sheppard, C. E., De Gara, C. J., et al. (2016). Financial costs and patients' perceptions of medical tourism in bariatric surgery. Canadian Journal of Surgery, vol. 59, no. 1, pp. 59-61.

[7] Badan Pusat Statistik Provinsi Bali. (2016). Kedatangan wisatawan mancanegara (wisman) ke Bali pada bulan Juni 2016 mencapai 405.835 kunjungan. Bali.

[8] Medibank Australia. (2010). Obesity in Australia: Financial impacts and cost benefits of intervention. 